\title{
The online presence of Turkish banks: Communicating the softer side of corporate identity
}

\author{
Emel Ozdora-Aksak $^{\mathrm{a}, *}$, Sirin Atakan-Duman ${ }^{\mathrm{b}}$ \\ a Bilkent University, Faculty of Fine Arts, Design and Architecture, Department of Communication and Design, Turkey \\ b Turgut Ozal University, Faculty of Economics and Administrative Sciences, Department of Business Administration, Turkey
}

\section{A R T I C L E I N F O}

\section{Article history:}

Received 9 May 2014

Received in revised form 29 August 2014

Accepted 8 October 2014

\section{Keywords:}

Corporate social responsibility

Public relations

Organizational identity

Banking sector

Qualitative analysis

Social media

\begin{abstract}
A B S T R A C T
This study tries to understand the process of organizational identity construction and the role of public relations in assisting this process. This study focuses on Turkey's banking sector to understand how organizational identities are constructed and supported by corporate social responsibility (CSR) activities in addition to how they are communicated to stakeholders. The corporate websites and social media accounts (Facebook and Twitter) of the eight largest banks in Turkey are examined through thematic content analysis to understand their identity construction processes and how much they benefit from CSR activities in this process. Institutional theory is utilized in this study to get a deeper understanding of the role of CSR in organizational identity construction. The results reveal that online presence of banks in Turkey tends to emphasize the softer, especially socially responsible side of their organizational identities.
\end{abstract}

(C) 2014 Elsevier Inc. All rights reserved.

\section{Introduction}

The Internet is increasingly becoming an important public relations tool for organizations to communicate with their publics; the authors argue that this medium would also be an important tool for organizational identity construction and communication of corporate social responsibility (CSR) activities. The focus of this study is the role of public relations and CSR practices in constructing an organization's identity. Public relations is one of the major organizational communication tools to construct an organization's identity and communicate this identity to relevant stakeholders. In fact, the role of public relations practitioners is to re-enforce organizational identity through communication activities.

This study analyzes a total of eight public and private banks in Turkey's banking sector with more than 300 branches, and investigates the role of public relations and CSR practices in constructing their organizational identities. In order to analyze the banks' organizational identity, the researchers examine their corporate websites and social media accounts (Facebook and Twitter) through thematic content analysis.

This research focuses on the role of public relations in constructing organizational identity by bringing together the literatures of public relations and organization studies, concentrating on external stakeholders, and using qualitative and quantitative techniques to understand this relationship in detail. In addition, the study also tries to bring a different theoretical perspective to the field of public relations through the focus on social identity theory while also analyzing social media, which over the last couple of years, has become increasingly popular in public relations research.

\footnotetext{
* Corresponding author. Tel.: +90 3122901061.

E-mail addresses: emel.ozdora@bilkent.edu.tr (E. Ozdora-Aksak), sduman@turgutozal.edu.tr (S. Atakan-Duman).
} 


\section{Literature review}

\subsection{Public relations and organizational identity}

Organizations use public relations to communicate and establish relationships with their stakeholders. Public relations has been defined as a management function which helps to build, nurture, and strengthen mutually beneficial relationships between an organization and its publics (Bruning \& Ledingham, 2000; Cutlip, Center, \& Broom, 2000; Ki \& Hon, 2007; Ledingham, 2006). Public relations has been used as a organizational function to reflect an organization's identity and image to its publics (Bromley, 1993; Dowling, 1994; Dutton \& Dukerich, 1991; van Riel, 1995). Organizations use public relations to connect with their publics through various means and by using different media such as publications, websites, and more increasingly social media.

One of the important roles of public relations is to help construct and communicate an organization's identity. Organizational identity puts forth what the organization is (Balmer, 1995; Hatch \& Schultz, 2002; van Rekom, 1997; van Riel 1995). As Bick, Jacobson, and Abratt (2003: 839) defined: "identity is the embodiment of the organization" and it communicates "the core values, philosophy and the strategy of the organization through the delivery of its products and/or services". It can be conceptualized as the personality and the soul of the corporation (Lee, 1983). Abratt (1989) defines organizational identity as "the collection of the physical and behavioral characteristics that represent and distinguish the company" (p. 68). Therefore, all organizational activities, products/services, and communication efforts play a role in identity construction (Olins, 1989).

Legitimacy is critical for organizations. According to institutional theorists, the institutional environment determines the socially constructed rules and requirements which organizations have to comply with in order to gain legitimacy (Meyer \& Rowan, 1977; Scott, 1995). Therefore organizations try to adapt to their environments and conform to environmental norms to increase their chances of survival. This means that organizations manage to survive and gain legitimacy by copying each other's actions. The norms and values of the organizational field, the context where socially constructed practices are reproduced and outspread (Greenwood, Suddaby, \& Hinings, 2002), determine organizational norms (Kondra \& Hinnings, 1998). Therefore, organizations need to adapt to the rules and requirements of the environment not only for efficiency, but also to gain legitimacy (Kondra \& Hinnings, 1998). Gaining legitimacy is critical for the survival and success of organizations and many try to gain legitimacy through CSR practices. As Fombrun and Shanley (1990) argue, publics today care about the non-economic agendas of organizations. In fact, there is increased concern about the organizations' added value to the society not just financial but also the non-financial benefits (Pfeffer \& Salancik, 1978). As Claasen and Roloff (2011) argued, an influential way to gain legitimacy is making CSR practices highly visible through an organization's communication efforts.

\subsection{Public relations and corporate social responsibility}

Strategic public relations efforts usually focus on connecting an organization with a socially responsible cause that fits the organization's mission and business activities, enhancing reputation through CSR and communicating about these CSR efforts with the organization's stakeholders. CSR has moral, ethical, and social implications that promote mutually beneficial relationships between an organization and its publics, which caused it to be also referred to as the "goodwill capital" of organizations (David, Kline, \& Dai, 2005, p. 293). The goal of CSR is not short-term profits but doing good for the society (J.E. Grunig, 2000). Lai, Chiu, Yang, and Pai (2010) defined CSR as "voluntary activities taken by corporations to enhance economic, social and environmental performance voluntarily" (p. 458). The authors argued, "CSR and corporate reputation arouse customers' emotional perceptions about the firms they deal with, leading them to associate their perceptions with the brands they intend to purchase, thus developing brand equity as well as enhancing corporate reputation" (Lai et al., 2010, p. 459). In this new CSR-driven business era, public relations professionals and scholars need to understand how different CSR initiatives may influence an organization's reputation. This knowledge may assist professionals to strategically guide companies when planning and implementing CSR practices.

Having a strong CSR program might be seen by many as a strategic decision by organizations to improve their reputations and gain a competitive edge. However, CSR programs should not only serve the organization for image/reputation management purposes, but also benefit their publics and the society at large by supporting different social causes such as human rights, education, gender, anti-discrimination, children, environment, health, quality products/services, etc. (Lee, Mak, \& Pang, 2012). In their study, David et al. described discretionary CSR practices as: "contributes resources to the arts and cultural programs in the community"; "contributes resources to raise social awareness of issues such as hunger and domestic violence"; "supports children and family issues, such as adoption and foster care"; and "supports public health programs” (David et al., 2005, p. 303). Many researchers argue that communicating an organization's CSR practices is critical for shaping stakeholders' views of CSR practices (David et al., 2005; Epstein \& Roy, 2001; Kim, 2011; Maignan \& Ferrell, 2001). Communication of CSR should focus mainly on establishing a linkage between an organization's image and its CSR practices. Epstein and Roy (2001) have even argued that a key performance measure of a successful CSR campaign is its communication and promotion to key publics, including the community.

CSR programs usually reflect an organization's culture, values and identity and they generally target key publics, including consumers, employees, and the community. Selvi, Wagner, and Türel (2010) analyzed Capital's “The most admired companies in Turkey" and "The leaders in social responsibility in Turkey" lists and compared the firm-year observations of companies before and companies after the financial crisis. The study results revealed a positive relationship between corporate social 
performance and reputation, leading to better financial performance and increased firm value or market share. These results reveal that CSR plays an important role in Turkey's business sector.

As social media is increasingly becoming a critical tool for public relations professionals to communicate with their stakeholders, this new media is also becoming an important tool for the communication of CSR practices. As Pavitt (2012) argued, organizations must catch the new communication technology and social media trends and should also realize that they can no longer "evade their responsibility to act ethically and responsibly as a true corporate citizen" (p. 25). Because social media allows for interaction and two-way communication, organizations do not have the luxury to ignore the questions or demands of their stakeholders. Thus, the researchers assume that the CSR efforts of companies will be visible on their social media accounts and they need to win the publics over about being responsible "corporate citizens".

\subsection{Public relations and social media}

The Internet and social media are increasingly becoming used for public relations purposes as they allow for interaction between the organization and its publics and help publics engage with organizations by asking questions, sharing content, or having conversations (Bonsón \& Ratkai, 2013; Hill \& White, 2000; Ye \& Ki, 2012). In fact, as Pavitt (2012) argued, public relations has also evolved with the increasing use of the Internet and social networks as it is no longer limited to sending letters to the editor or trying to get news releases published by using your connections with journalists. This is a natural result of the increased use of social networks because "organisations can no longer hide behind closed doors, just telling their stakeholders what they think they need to know" (Pavitt, 2012, 24).

After the Internet was introduced in mid-1990s, public relations professionals quickly realized its potential for enhancing communication and fostering relationships between an organization and its publics. The academy did not lag too much behind as communication scholars started to examine social media as a new and developing tool for business communication (Bonsón \& Ratkai, 2013). Two-way communication with publics can be established through the use of Internet and social media in addition to monitoring public opinion, collecting detailed information about stakeholders and having dialog with them (McAllister \& Taylor, 2007; van der Merwe, Pitt, \& Abratt, 2005). Just like its use for public relations professionals to create two-way communication opportunities has increased in the U.S. (Diga \& Kelleher, 2009), European public relations practitioners also benefit from these fast-developing online networks to engage with their publics (Verhoeven, Tench, Zerfass, Moreno, \& Vercic, 2012). The popular use of the Internet and social networks seems to have evolved similarly in Turkey as well. Public relations professionals in Turkey also agree with the potential of social media as an opportunity for public relations and use it to engage with their publics (Alikilic \& Atabek, 2012). However this interactive medium also allows for publics to be more active and even try influencing organizations to act in certain ways. Individuals can now make virtual connections and push organizations to create change through the interactive medium of social media (Pavitt, 2012).

In fact, Turkey is a major user of social media. In Turkey, 45 percent of the population ( 35 million users) had access to the Internet in 2011, making Turkey the fifth largest Internet user in Europe and second largest in Eastern Europe after the Russian Federation (Internet World Stats, 2012). According to Comscore (2011), Internet users in Turkey spend an average of 32 hours per month online, making them the most engaged users in Europe (Comscore, 2011). Just like the use of Internet is popular in Turkey, people are also in favor of using social media very actively. According to Alikilic and Atabek (2012), Turkey has the third largest population of Facebook users in the world. As the use of social media has increased, the opportunities they create for people and businesses have also revealed themselves.

The increasing popularity of social media creates many opportunities for public relations professionals as well as academicians. In fact, research related to internet use for public relations has increased between 1992 and 2009, and started to focus more on the interactions between organizations and their publics (Ye \& Ki, 2012). This research also aims to contribute to this growing literature by providing insight about how websites and social media accounts are being used for public relations purposes by the banking sector in Turkey. The research will also try to illustrate how much organizations focus on their CSR efforts on their social media accounts. The research is significant as it aims to develop a measurement instrument to help measure online organizational communication and try to bring public relations scholars and professionals closer.

Therefore this study aims to understand the following research questions:

$R Q 1$. Which themes and theme categories do banks in Turkey emphasize on their corporate websites?

$R Q$ 2. What is the role of CSR in this identity construction, how much is CSR emphasized on corporate websites?

$R Q$ 3. How much do these banks utilize social media accounts for identity construction, do they try to reflect the identity constructed on corporate websites?

$R Q 4$. How much is CSR communicated/emphasized on the social media accounts of these banks?

The following section introduces the methods used for data collection and coding from the websites and social media accounts of Turkish banks. Then, the results section explains the website analysis and social media analysis findings in two subheadings followed by a comparison of the results. The discussion and conclusions section highlights the implications of the results and reveals the patterns used by banks in their online presence and the differences between state-owned versus private banks. The study limitations and implications for future research section includes suggestions for future researchers who would like to pursue a similar research agenda. 


\section{Methodology}

As van Rekom (1997) argued, corporate identity research should start with qualitative analysis in which organizationspecific elements are gathered to derive adequate identity statements from an organization's "factual corporate identity" (p. 415). In fact, the qualitative researcher adopts an inductive approach and works with the data as it emerges to uncover "the multiple interrelationships among dimensions that emerge from the data without making prior assumptions or specifying hypotheses about the linear or correlative relationships among narrowly defined, operationalized variables" (Patton, 2002, p. 56). The qualitative researcher seeks to comprehend deeper meanings and understand interrelationships in the data. Furthermore, as van Riel and Balmer (1997) suggested, an interdisciplinary approach is required when studying corporate identity. This study attempts to determine how organizations define themselves and communicate their distinctive characteristics to create a positive public identity through their websites and social media accounts. The language used on the websites and social media accounts to communicate organizational identity is the main focus of the study as language is an important tool for constructing meaning through social interaction (Berger \& Luckmann, 1966). Sundaramurthy and Kreiner (2008) also emphasized the importance of language by referring to it as a "manifestation of cultural values" (p. 419). In addition, this research aims to understand the influence of CSR activities on organizational identity construction and highlights the relative significance and influence of CSR activities on organizational identity construction.

Eight largest public and private banks in Turkey's banking sector with more than 300 branches were investigated in this study. Out of the eight banks studied, three are public; Ziraat Bank with a total of 1492 branches, Halk Bank with 823 branches and Vakıf Bank with 741 branches and five are privately-owned; Ak Bank with 974 branches, Turk Economy Bank (TEB) with 507 branches, Garanti Bank with 926 branches, İş Bank with 1233 branches and Yapı Kredi Bank with 927 branches (Türkiye Bankalar Birliği, 2013). The research makes use of only secondary data while focusing on the websites and social media accounts of the eight banks at the corporate level.

\subsection{Website analysis}

The textual data was collected from the about us, history, mission and vision, and corporate social responsibility sections of each bank's website. Content analysis was executed with pre-readings followed by detailed readings of the semiotic content, which helped determine the main themes, ideas, and issues to enlighten the research questions. Content analysis was used as it is the "systematic reading of a body of texts, images and symbolic material, not necessarily from the author's perspective" (Krippendorf, 2004, p. 3). In fact, one of the most commonly used technique to analyze information about organizations is content analysis (Bonsón, Escobar, \& Flores, 2008; Ettredge, Richardson, \& Scholz, 2001; Gallego-Alvarez, Rodriguez-Dominguez, \& Garcia-Sanchez, 2011).

Dominant themes were identified through focusing on certain issues and concepts expressing distinctive characteristics of each bank. Themes were later categorized under comprehensive headings to develop theme categories. The theme categories obtained from the analysis were compared to determine the unique positioning of each bank and CSR activities in communicating its organizational identity. The analysis also revealed the variations in each bank's use of CSR in the organizational identity construction and communication process.

\subsection{Social media analysis}

The posts and photos shared on active social media accounts (Facebook and Twitter) of the eight banks during a fourmonth period between March and July 2013 were collected on a separate word document and analyzed both quantitatively and qualitatively. The number of posts and photos were first counted to reveal and compare the usage of social media accounts by different banks. In addition, the content of the posts was thematically analyzed through a social media measurement instrument. The instrument was modified by the researchers according to the research questions of this study from the social media measurement tool developed by Lo and Waters (2013). CSR dimensions were also added to the measurement instrument to reveal the role of CSR in online identity construction.

The measurement instrument mainly focuses on the following dimensions: tone of language used in the posts, personal vs. formal language; frequency of posts; use of two-way communication and encouragement of interaction (allowing and responding to comments); reference to mission and goals; reference to organizational achievements; emphasis on CSR activities; and finally use of multi-media (sharing organizational photos and videos).

\section{Results}

The results are presented in two different subheadings - website and social media analysis - to make research findings easier to follow and compare.

\subsection{Website analysis}

As mentioned before, the texts published by each bank on their websites constitute the data set of an in-depth conceptual analysis conducted for a previous study (Atakan-Duman \& Ozdora-Aksak, 2014). Results revealed that each bank utilizes a 
Table 1

Theme categories that came out of the thematic website analysis.

\begin{tabular}{|c|c|c|c|c|}
\hline \multicolumn{5}{|l|}{ Theme categories } \\
\hline $\begin{array}{l}\text { Extensive impact and } \\
\text { development }\end{array}$ & Future orientation & Being ethical & Superiority & Core banking functions \\
\hline $\begin{array}{l}\text { - Sustainability } \\
\text { - Growth/leap } \\
\text { - Being international } \\
\text { - Collaboration/partnership }\end{array}$ & $\begin{array}{l}\text { - Contemporary banking } \\
\text { - Being technological } \\
\text { - Change/renewal } \\
\text { - Innovation/creativity }\end{array}$ & $\begin{array}{l}\text { - Openness/honesty/trustworthiness } \\
\text { - Equal opportunity/fairness } \\
\text { - Corporate social responsibility } \\
\text { - Benefit the society and economy }\end{array}$ & $\begin{array}{l}\text { - Respectability } \\
\text { - Being the first } \\
\text { - Being the leader } \\
\text { - Being a strong bank } \\
\text { - Being competitive }\end{array}$ & $\begin{array}{l}\text { - Create value } \\
\text { - Profitability } \\
\text { - Productivity } \\
\text { - Being customer oriented } \\
\text { - Qualified personnel } \\
\text { - SME banking }\end{array}$ \\
\hline
\end{tabular}

different set of themes to identify itself and continuously communicates its identity through these distinctive word groups. The theme categories were derived from the analysis of texts on the homepages, about us sections and other related general content pages of the banks' websites in addition to their corporate social responsibility sections. First distinctive themes emphasized by the banks were identified and coded. Later these themes were grouped into theme categories according to their functions for identity construction. The theme categories that came out of the thematic website analysis were extensive impact and development, future orientation, being ethical, superiority, and core banking functions (Table 1).

The extensive impact and development theme category includes themes that emphasize sustainability, growth/leap, being international, and collaboration/partnership. Future orientation includes a focus on contemporary banking, being technological, change/renewal, and innovation/creativity. Another important theme category was being ethical which focused on openness/honesty/trustworthiness, equal opportunity/fairness, benefiting the society and economy, and corporate social responsibility. The theme category superiority was developed by grouping themes such as respectability, being the first, being the leader, being a strong bank, and being competitive. The final theme category was core banking functions that included creating value, profitability, productivity, being customer oriented, having qualified personnel, and SME banking. The most popular theme categories used by each bank and their relative weight is presented in Table 2. As this table reveals while state-owned public banks communicate core banking functions and extensive impact and development theme categories more heavily, private banks tend to construct their identities through superiority, being ethical, future orientation in addition to extensive impact and development.

\subsection{Social media analysis}

In addition to the website analysis, social media accounts of these eight banks were studied quantitatively and qualitatively to understand how they utilize their social media accounts for identity construction during a four-month period. Their frequency of use, number of posts and number of photos shared were examined to reveal the differences in social media use of these banks as presented in Table 3. The banks have been grouped according to their ownership private versus public and the comparison immediately reveals that privately-owned banks use social media more heavily while public banks lag behind in terms of their social media presence.

The results of the analysis revealed that all of the banks analyzed are still learning and experimenting with social media. It is safe to say that there is no bank that shares content (Facebook posts, tweets or photos) every day. However, Ak Bank, Garanti and TEB are the most effective users of social media relative to the other banks analyzed. These three banks shared more posts and photos, making them more active users of Facebook and Twitter. Halk Bank lags behind in social media adoption and does not even have a Facebook account while rarely using Twitter.

Table 4 presents the social media use summary of the banks. The state owned banks do not emphasize their institutional identities via social media, they tend to use a formal language in their posts or tweets and they do not engage in two-way communication. Almost all banks use a collective tone and casual language in their social media accounts except for Ziraat Bank and İs Bank. The authors believe that because these two are state banks they might be trying to keep their formal "state bank tone" in the social media accounts. In addition Ziraat Bank is the only bank that still uses one-way communication rather than two-way, which is preferred by all the other banks. The analysis revealed that all of the banks reflect the identity themes they use on their websites on their social media accounts as well. A detailed analysis of the banks reveal that privately-owned banks tend to be more professional, up-to-date, and active in the way they manage their social media accounts whereas two of the state banks studied almost have no social media presence and do not seem to be taking the issue very seriously either.

The results of the website analysis of these eight banks showed that banks utilize their CSR initiatives to differentiate themselves from their competitors while constructing their identities. As Table 4 indicates the three public banks, Vakıf, Ziraat and Halk banks are significantly different than their private counterparts in terms of social media use. They do not have an emphasis on societal impact and customers, their social media posts are irregular and daily, they tend to use formal language and most significantly they do not engage in two-way communication. Apart from Ziraat Bank and Halk Bank which are state-owned banks, all of the other banks mentioned CSR on their social media accounts similar to their websites. This finding underlines the fact that the banks studied also try to highlight their softer side, their CSR initiatives and consequently win the support of their current and potential customers. 
Table 2

Most popular theme categories used by each bank.

\begin{tabular}{|c|c|c|c|c|c|c|c|c|c|c|c|c|c|c|c|c|}
\hline \multirow[t]{4}{*}{ Theme categories } & \multicolumn{16}{|c|}{ Banks } \\
\hline & \multicolumn{10}{|c|}{ Privately-owned mutual savings banks } & \multicolumn{6}{|c|}{ State-owned mutual savings banks } \\
\hline & \multicolumn{2}{|c|}{ Yapı Kredi } & \multicolumn{2}{|c|}{ T. İş Bank } & \multicolumn{2}{|c|}{ TEB } & \multicolumn{2}{|c|}{ Garanti Bank } & \multicolumn{2}{|c|}{ Ak Bank } & \multicolumn{2}{|c|}{ Vakıf Bank } & \multicolumn{2}{|c|}{ Ziraat Bank } & \multicolumn{2}{|c|}{ Halk Bank } \\
\hline & & $\%$ & & $\%$ & & $\%$ & & $\%$ & & $\%$ & & $\%$ & & $\%$ & & $\%$ \\
\hline Superiority & 3 & 12.00 & 4 & 57.14 & 13 & 35.14 & 17 & 27.87 & 9 & 25.00 & - & - & 3 & 10.00 & 5 & 8.06 \\
\hline Core banking functions & 4 & 16.00 & - & - & 12 & 32.43 & 8 & 13.11 & 7 & 19.44 & 5 & 35.71 & 15 & 50.00 & 28 & 45.16 \\
\hline Extensive impact and development & 5 & 20.00 & 3 & 42.86 & 9 & 24.32 & 16 & 26.23 & 4 & 11.11 & 6 & 42.86 & 8 & 26.66 & 11 & 17.74 \\
\hline Being ethical & 13 & 52.00 & - & - & - & - & 11 & 18.03 & 10 & 27.77 & 3 & 21.43 & - & - & 9 & 14.52 \\
\hline Future orientation & - & - & - & - & 3 & 8.11 & 9 & 14.75 & 6 & 16.66 & - & - & 4 & 13.33 & 9 & 14.52 \\
\hline Total & 25 & & 7 & & 37 & & 61 & & 36 & & 14 & & 30 & & 62 & \\
\hline
\end{tabular}


Table 3

Content and post count of social networking sites.

\begin{tabular}{|c|c|c|c|c|}
\hline \multirow[t]{2}{*}{ Banks } & \multicolumn{2}{|l|}{ Facebook } & \multicolumn{2}{|l|}{ Twitter } \\
\hline & Number of posts & Number of photos & Number of tweets & Number of photos \\
\hline \multicolumn{5}{|c|}{ Privately-owned mutual savings banks } \\
\hline Ak Bank & 138 & 88 & 291 & 45 \\
\hline Garanti & 134 & 94 & 151 & 13 \\
\hline TEB & 122 & 89 & 309 & 24 \\
\hline Yapı Kredi & 72 & 50 & 191 & 4 \\
\hline İş Bank & 42 & 40 & 66 & 5 \\
\hline \multicolumn{5}{|c|}{ State-owned mutual savings banks } \\
\hline Ziraat Bank & 52 & 86 & 158 & 27 \\
\hline Vakıf Bank & 48 & 65 & 71 & 3 \\
\hline Halk Bank & - & - & 39 & - \\
\hline
\end{tabular}

Table 4

Social media summary of Turkish banks.

\begin{tabular}{|c|c|c|c|c|c|c|c|c|}
\hline & \multicolumn{8}{|l|}{ Banks } \\
\hline & \multicolumn{5}{|c|}{ Privately-owned mutual savings banks } & \multicolumn{3}{|c|}{ State-owned mutual savings banks } \\
\hline & Yapı Kredi & İş Bank & TEB & Garanti & Ak Bank & Ziraat & Vakıf Bank & Halk Bank \\
\hline Facebook & & & & & & & & Facebook analysis \\
\hline ‘About Us’ & & & & & & & & could not be conducted \\
\hline Emphasis on the institution & $\sqrt{ }$ & $\sqrt{ }$ & $\sqrt{ }$ & $\sqrt{ }$ & $\sqrt{ }$ & $\sqrt{ }$ & $\sqrt{ }$ & as the bank does not \\
\hline Emphasis on society & $\sqrt{ }$ & & & & & & & have an active account \\
\hline $\begin{array}{l}\text { Emphasis on the themes derived } \\
\text { out from the analysis }\end{array}$ & $\sqrt{ }$ & $\sqrt{ }$ & $\sqrt{ }$ & $\sqrt{ }$ & $\sqrt{ }$ & $\sqrt{ }$ & $\sqrt{ }$ & \\
\hline \multicolumn{9}{|l|}{ Status } \\
\hline Emphasis on the Institution & & $\sqrt{ }$ & $\sqrt{ }$ & $\sqrt{ }$ & $\sqrt{ }$ & & $\sqrt{ }$ & \\
\hline Emphasis on society & $\sqrt{ }$ & & & $\sqrt{ }$ & $\sqrt{ }$ & & & \\
\hline Collective tone of the language & $\sqrt{ }$ & & $\sqrt{ }$ & $\sqrt{ }$ & $\sqrt{ }$ & & $\sqrt{ }$ & \\
\hline Use of formal language & & $\sqrt{ }$ & & & & $\sqrt{ }$ & & \\
\hline 2-Way communication & $\sqrt{ }$ & $\sqrt{ }$ & $\sqrt{ }$ & $\sqrt{ }$ & $\sqrt{ }$ & & $\sqrt{ }$ & \\
\hline Emphasis on the customers & $\sqrt{ }$ & & & & $\sqrt{ }$ & & & \\
\hline Frequency of posts (everyday) & & & & & & & & \\
\hline Reference to current CSR programs & $\sqrt{ }$ & & $\sqrt{ }$ & $\sqrt{ }$ & $\sqrt{ }$ & & $\sqrt{ }$ & \\
\hline \multicolumn{9}{|l|}{ Twitter } \\
\hline Emphasis on the Institution & $\sqrt{ }$ & $\sqrt{ }$ & $\sqrt{ }$ & $\sqrt{ }$ & $\sqrt{ }$ & $\sqrt{ }$ & $\sqrt{ }$ & $\sqrt{ }$ \\
\hline Emphasis on society & $\sqrt{ }$ & & $\sqrt{ }$ & $\sqrt{ }$ & $\sqrt{ }$ & $\sqrt{ }$ & & $\sqrt{ }$ \\
\hline Collective tone of the language & $\sqrt{ }$ & & & & $\sqrt{ }$ & & $\sqrt{ }$ & \\
\hline Use of formal language & & & & & & $\sqrt{ }$ & & $\sqrt{ }$ \\
\hline 2-Way communication & $\sqrt{ }$ & & $\sqrt{ }$ & $\sqrt{ }$ & $\sqrt{ }$ & & & \\
\hline Emphasis on the customers & $\sqrt{ }$ & & $\sqrt{ }$ & $\sqrt{ }$ & $\sqrt{ }$ & $\sqrt{ }$ & & $\sqrt{ }$ \\
\hline Frequency of posts (everyday) & & & & $\sqrt{ }$ & & & & \\
\hline Reference to current CSR programs & $\sqrt{ }$ & & $\sqrt{ }$ & $\sqrt{ }$ & $\sqrt{ }$ & & $\sqrt{ }$ & \\
\hline
\end{tabular}

$\sqrt{ }$, the presence of the subheading for the specified bank.

Among all banks only Garanti Bank actively uses Twitter every day. All the banks have a customer focus in Twitter accounts and tweets with the exception of İş Bank and Halk Bank. In addition, all banks use a friendly tone and casual language in their Twitter accounts except for Ziraat Bank and Halk Bank. Moreover, half of the largest banks in Turkey, Ziraat, Vakıf, İş and Halk Bank, use one-way communication in Twitter which is surprising when one considers the interactive engagement opportunities provided by this medium.

Similar to the results of the Facebook analysis, current CSR programs are utilized by banks in Twitter accounts to reflect their commitment to the community and strengthen their corporate identities. However the state-owned banks, Ziraat, İş and Halk Bank, do not emphasize current CSR programs in their Tweets. The preliminary reading of the results revealed a significant distinction among banks in terms of being state-owned and the date of establishment. These results will be further discussed in the following section.

\section{Discussion and conclusion}

The two most common themes emphasized by almost all the eight banks were corporate social responsibility and sustainability. These results are striking, as banks do not construct their identities with their core banking functions, meaning their economic outputs; instead they accentuate their identity through non-economic outputs. More specifically, all of the banks utilize CSR as a distinctive identity factor, except for TEB. Similarly, the sustainability theme is also a distinctive theme 
factor utilized by all the banks except TEB and Halk Bank. On the other hand, the most commonly emphasized economic output is found to be customer orientation, which is emphasized by all banks except for Yapı Kredi and İs Bank. In summary, these findings indicate that Turkey's eight largest banks prefer to highlight non-economic outputs when communicating their identities to their stakeholders. Among these non-economic outputs, engaging in CSR and being ethical plays a special role in the identity construction process (Table 2), especially for privately owned banks.

This finding supports the argument put forth by McWilliams, Siegel, and Wright (2006) that established organizations invest more in CSR. The underlying motive behind emphasizing CSR is the goal of being perceived as a good corporate citizen by all stakeholders (Maignan \& Ferrell, 2001) and building a strong reputation (Brammer, Millington, \& Rayton, 2007). As institutional theory suggests, compliance to the organizational environment is vital for both organizational survival and competitiveness. This pressure to adapt to the environment is rooted not only in efficiency concerns, but also in the need to gain legitimacy (Kondra \& Hinnings, 1998). Although banks exist on their core banking functions, which are solely economic, they strive to construct their identities on non-economic concerns in order to be perceived as trustworthy corporate citizens that exist for the benefit of society. Fombrun and Shanley (1990) also argue that publics care about the non-economic agendas of organizations. In fact, communicating non-economic agendas, especially CSR related activities, has become a critical public relations tactic to gain legitimacy and competitive advantage. Organizations increasingly integrate CSR into their public relations agendas and emphasize CSR in their communication efforts. This research reveals that regardless of its core business function, an organization has to communicate non-economic social concerns for constructing an identity as well as gaining and sustaining legitimacy.

Most of the banks prefer a casual fun tone to communicate on social media, which suits the nature and format of this medium. In addition, none of the banks share their annual reports or other official reports on their social media accounts although they are available on their corporate websites. This goes parallel with the casual non-hierarchical and engagementpromoting nature of social media. Similarly, a customer-focused approach can be observed in most of the banks' social media accounts, which is native to social media but cannot be observed in their corporate websites. More specifically, research results revealed that state owned and older banks (Ziraat, İş Bank and Halk Bank) tend to be less active in their use of social media.

Another important result of the analysis is how much banks emphasize their CSR efforts on social media. Specifically Yapı Kredi and Garanti banks highlight their CSR initiatives relative to other banks analyzed, especially focusing on the variety including education, environment, sports and social programs. This study contributes to the literature by revealing the significance of CSR for the public relations and identity construction efforts of organizations. The scope of this research allowed researchers to identify varying number of themes utilized by banks to construct and communicate their identities. Although related literature frames CSR as a strategic management tool to improve corporate reputation and increase return on investment, CSR ultimately serves the community. It increases social welfare and allows members of the society to benefit from services provided by organizations.

The results presented in Tables 2 and 4 clearly reveal that there is a significant distinction between state-owned public banks and privately owned banks in terms of the themes and theme categories they utilize for identity construction. Public banks, Vakıf, Ziraat and Halk banks, rely more heavily on core banking functions and extensive impact and development theme categories to construct their identities. One reason for this preference might be the state assurance behind them, as they do not need to gain public trust by emphasizing themes which highlight being ethical such as CSR, equal opportunity and fairness, and openness, honesty and trustworthiness. Similarly they do not have future concerns as they are aided by the state; therefore public banks, as expected, do not heavily stress the theme category future orientation. In addition, public banks do not need to prove their superiority as they are owned by the state and as a result they do not heavily accentuate their superiority in comparison to other banks. Superiority, being ethical and having a future orientation theme categories are believed to be directly related with gaining legitimacy, however public banks do not have legitimacy concerns as they already have a legitimate identity by being state-owned institutions. Consequently, they differentiate themselves from their privately owned competitors by emphasizing themes which highlight core business functions such as being very good at SME banking and their extensive impact for the national economy and the development of the society.

On the other hand, privately owned banks tend to construct and communicate their identities through utilizing themes that highlight superiority, being ethical, future orientation in addition to extensive impact and development. Private banks have to gain legitimacy as their basis of existence is under question and they have to construct an identity beyond being a profit seeking entity that might engage in unethical practices for its own survival and success. In addition, the future and sustainability of these banks is not secured by the state, therefore employing themes that focus on their future orientation appears to be another way to gain legitimacy for private banks and promise sustainability to current and potential customers.

\subsection{Study limitations and implications for future research}

The relationship between the robustness of these banks' on-line communications presence and their overall financial success has not been studied in this paper as it requires a different analysis which is beyond the scope of this study. However it provides a significant research question for future research. In addition this study is only limited to the eight largest mutual savings banks in Turkey but future research may increase this number by including other types of banks such as Islamic banks. Furthermore, this study is based on secondary data nonetheless in order to understand internal decision 
making processes and policies of banks in constructing their organizational identities primary data such as interview could be utilized in future studies.

\section{Acknowledgements}

The authors would like to thank the anonymous reviewers for their valuable insights and suggestions which helped make the paper stronger. In addition, Berrak Esen and Melike Tigli cannot be thanked enough for helping with the long and tedious data collection process for this paper. This work has been funded by The Scientific and Technological Research Council of Turkey (TUBITAK), grant no. 114K096.

\section{References}

Abratt, R. (1989). A new approach to the corporate image management process. Journal of Marketing Management, 5(1), 63-76.

Alikilic, O., \& Atabek, U. (2012). Social media adoption among Turkish public relations professionals: A survey of practitioners. Public Relations Review, 38, 56-63.

Atakan-Duman, S., \& Ozdora-Aksak, E. (2014). The role of corporate social responsibility in online identity construction: An analysis of Turkey's banking sector. Public Relations Review, http://dx.doi.org/10.1016/j.pubrev.2014.07.004

Balmer, J. M. T. (1995). Corporate branding and connoisseurship. Journal of General Management, 21(1), 22-46.

Berger, P. L., \& Luckmann, T. (1966). The social construction of reality. Middlesex, England: Penguin Books.

Bick, G., Jacobson, M. C., \& Abratt, R. (2003). The corporate identity management process revisited. Journal of Marketing Management, 19(7-8), 835-855.

Bonsón, E., Escobar, T., \& Flores, F. (2008). Navigation quality as a key value for the webpage of a financial entity. Online Information Review, 32(5), 623-634.

Bonsón, E., \& Ratkai, M. (2013). A set of metrics to assess stakeholder engagement and social legitimacy on a corporate Facebook page. Online Information Review, 37(5), 787-803.

Brammer, S., Millington, A., \& Rayton, B. (2007). The contribution of corporate social responsibility to organizational commitment. The International Journal of Human Resource Management, 18(10), 1701-1719.

Bromley, D. B. (1993). Reputation, image and impression management. New York: Wiley.

Bruning, S. D., \& Ledingham, J. A. (2000). Perceptions of relationships and evaluations of satisfaction: An exploration of interaction. Public Relations Review, 26, 85-95.

Claasen, C., \& Roloff, J. (2011). The link between responsibility and legitimacy: The case of De Beers in Namibia. Journal of Business Ethics, 107(3), 379-398.

Comscore. (2011). Turkey in the global internet and the future of online measurement. Presentation retrieved from http://www.comscore.com/ Insights/Presentations_and_Whitepapers/2011/Turkey_in_the_Global_Internet_and_The_Future_of_Online_Measurement

Cutlip, S. M., Center, A. H., \& Broom, G. M. (2000). Effective public relations (8th ed.). Englewood Cliffs, New Jersey: Prentice-Hall International, Inc.

David, P., Kline, S., \& Dai, Y. (2005). Corporate social responsibility practices, corporate identity, and purchase Intention: A dual-process model. Journal of Public Relations Research, 17(3), 291-313.

Diga, M., \& Kelleher, T. (2009). Social media use, perceptions of decision-making power, and public relations roles. Public Relations Review, 35, 440-442.

Dowling, G. R. (1994). Corporate reputations: Strategies for developing the corporate brand. London: Kogan Page.

Dutton, J. E., \& Dukerich, J. M. (1991). Keeping an eye on the mirror: Image and identity in organizational adaptation. Academy of Management Journal, 34, $519-554$

Epstein, M. J., \& Roy, M. J. (2001). Sustainability in action: Identifying and measuring the key performance drivers. Long Range Planning, 34, 585-604.

Ettredge, M., Richardson, V., \& Scholz, S. (2001). The presentation of financial information at corporate web sites. International Journal of Accounting Information Systems, 2(3), 14-68.

Fombrun, C., \& Shanley, M. (1990). What's in a name? Reputation building and corporate strategy. Academy of Management Journal, 33(2), 233-258.

Gallego-Alvarez, I., Rodriguez-Dominguez, L., \& Garcia-Sanchez, I. (2011). Information disclosed online by Spanish universities: Content and explanatory factors. Online Information Review, 35(3), 360-385.

Greenwood, R., Suddaby, R., \& Hinings, C. R. (2002). Theorizing change: The role of professional associations in the transformation of institutionalized fields. Academy of Management Journal, 45, 58-80.

Grunig, J. E. (2000). Collectivism, collaboration, and societal corporatism as core professional values in public relations. Journal of Public Relations Research, $12,23-48$.

Hatch, M. J., \& Schultz, M. (2002). The dynamics of organizational identity. Human Relations, 55(8), 989-1018.

Hill, L. N., \& White, C. (2000). Public relations practitioners' perception of the World Wide Web as a communication tool. Public Relations Review, 26, 31-51.

Internet World Stats. (2012). Top 20 countries with highest number of internet users - June 30, 2012. Retrieved from http://www. internetworldstats.com/top20.htm

Ki, E. J., \& Hon, L. C. (2007). Testing the linkages among the organization-public relationship and attitude and behavioral intentions. Journal of Public Relations Research, 19, 1-23.

Kim, S. (2011). Transferring effects of CSR strategy on consumer responses: The synergistic model of corporate communication strategy. Journal of Public Relations Research, 23(2), 218-241.

Kondra, A. Z., \& Hinnings, C. R. (1998). Organizational diversity and change in institutional theory. Organization Studies, 19(5), 743-767.

Krippendorf, K. (2004). Content Analysis: An introduction to its methodology. London: Sage.

Lai, C. S., Chiu, C. J., Yang, C. F., \& Pai, D. C. (2010). The effects of corporate social responsibility on brand performance: The mediating effect of industrial brand equity and corporate reputation. Journal of Business Ethics, 95(3), 457-469.

Ledingham, J. A. (2006). Relationship management: A general theory of public relations. In C. H. Botan, \& V. Hazleton (Eds.), Public relations theory II (pp. 465-483). Mahwah, NJ: Lawrence Erlbaum Associates.

Lee, R. (1983). Shaping your bank's corporate identity. Bank Marketing, 15(10), 21-24.

Lee, M. H., Mak, A. K., \& Pang, A. (2012). Bridging the gap: An exploratory study of corporate social responsibility among SMEs in Singapore. Journal of Public Relations Research, 24(4), 299-317.

Lo, K. D., \& Waters, R. D. (2013). Organizations in the social media sphere: Creating a new virtual culture or reinforcing traditional cultural dimensions? In Presented at international conference on intercultural research University of Nevada-Reno, June 23-27, 2013.

Maignan, I., \& Ferrell, O. C. (2001). Corporate citizenship as a marketing instrument. European Journal of Marketing, 35, 457-484.

McAllister, S., \& Taylor, M. (2007). Community college web sites as tools for fostering dialogue. Public Relations Review, 33, 230-232.

McWilliams, A., Siegel, D. S., \& Wright, P. M. (2006). Corporate social responsibility: Strategic implications. Journal of Management Studies, 43(1), 1-18.

Meyer, J. W., \& Rowan, B. (1977). Institutionalized organizations: Formal structure as myth and ceremony. American Journal of Sociology, 83, 340-363.

Olins, W. (1989). Corporate Identity: Making Strategy Visible through Design. London: Thames \& Hudson.

Patton, M. Q. (2002). Qualitative research and evaluation methods (3rd ed.). Thousand Oaks, CA: Sage.

Pavitt, H. (2012). No place to hide: New technological advances in Web 2.0 and Social Media may force organisations to improve their corporate social responsibility. Social Alternatives, 31(2), 22-26.

Pfeffer, J., \& Salancik, G. (1978). The external control of organizations: A resource dependence perspective. New York, NY: Harper \& Row. 
Scott, W. R. (1995). Institutions and organizations. Thousand Oaks, CA: Sage Publications.

Selvi, Y., Wagner, E., \& Türel, A. (2010). Corporate social responsibility in the time of financial crisis: Evidence from Turkey. Annales Universitatis Apulensis Series Oeconomica, 12(1).

Sundaramurthy, C., \& Kreiner, G. E. (2008). Governing by managing identity boundaries: The case of family businesses. Entrepreneurship Theory and Practice, $32(3), 415-436$.

Türkiye Bankalar Birliği. (2013). Turkish banks and their branches 2013. Retrieved from http://www.tbb.org.tr/modules/banka-bilgileri/banka_sube_bilgileri. asp?tarih $=16.01 .2013$

van der Merwe, R., Pitt, L., \& Abratt, R. (2005). Stakeholder strength: PR survival strategies in the Internet age. Public Relations Quarterly, 50(1), 39-48.

van Rekom, J. (1997). Deriving an operational measure of corporate identity. European Journal of Marketing, 31(5/6), 410-422.

van Riel, C. B. M. (1995). Principles of corporate communication. Hemel Hempstead, England: Prentice Hall.

van Riel, C. B. M., \& Balmer, J. M. T. (1997). Corporate identity: The concept, its measurement and management. European Journal of Marketing, 31(5/6), 340-355.

Verhoeven, P., Tench, R., Zerfass, A., Moreno, A., \& Vercic, D. (2012). How European PR practitioners handle digital and social media. Public Relations Review, $38,162-164$.

Ye, L., \& Ki, E. J. (2012). The status of online public relations research: An Analysis of published articles in 1992-2009. Journal of Public Relations Research, 24(5), 409-434. 